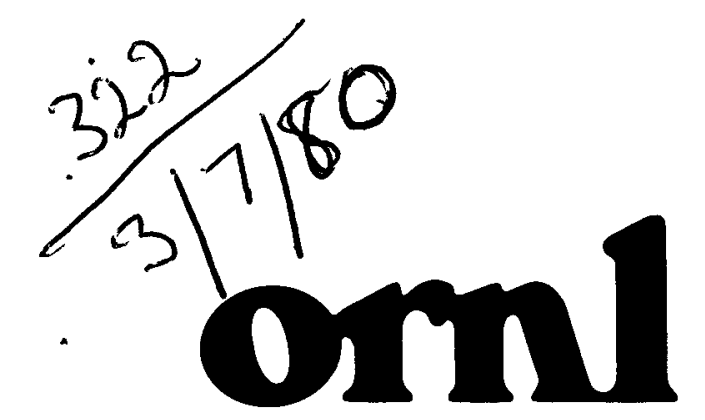

OAK RIDGE NATIONAL LABORATORY

UNION CARBIDE

\section{th. 809}

ORNL-5618

\title{
An Evaluation of the Low-Level Waste Treatment Plant at Oak Ridge National Laboratory, and Suggested Changes in the Design and Operation
}

J. M. Chilton

OPERATED BY

UNION CARBIDE CORPOBATION FOR THE UNITED STATES DEPARTMENT OF ENERGY 


\section{Printed in the United States of America Avallable from National Technical Information Service \\ US Department of Commerce \\ 5285 Port Royal Road, Sprıngfıeld, Vırgınıa 22161 \\ NTIS price codes-Printed Copy A03, Microfiche A01}

This report was prepared as an account of work sponsored by an agency of the United States Government Neither the United States Government nor any agency thereof, nor any of their employees, makes any warranty, express or implied or assumes any legal liability or responsibility for the accuracy, completeness, or usefulness of any information, apparatus, product, or process disclosed, or represents that its use would not infringe privately owned rights Reference herein to any specific commercial product, process, or service by trade name, trademark manufacturer, or otherwise, does not necessarily constitute or imply its endorsement, recommendation, or favoring by the United States Government or any agency thereof The views and opınıons of authors expressed hereın do not necessarily state or reflect those of the United States Government or any agency thereof 


\section{DISCLAIMER}

This report was prepared as an account of work sponsored by an agency of the United States Government. Neither the United States Government nor any agency Thereof, nor any of their employees, makes any warranty, express or implied, or assumes any legal liability or responsibility for the accuracy, completeness, or usefulness of any information, apparatus, product, or process disclosed, or represents that its use would not infringe privately owned rights. Reference herein to any specific commercial product, process, or service by trade name, trademark, manufacturer, or otherwise does not necessarily constitute or imply its endorsement, recommendation, or favoring by the United States Government or any agency thereof. The views and opinions of authors expressed herein do not necessarily state or reflect those of the United States Government or any agency thereof. 


\section{DISCLAIMER}

Portions of this document may be illegible in electronic image products. Images are produced from the best available original document. 
ORNL-5618

Dist. Category UC-70

Contract No. W-7405-eng-26

CHEMICAL TECHNOLOGY DIVISION

NUCLEAR FUEL AND WASTE PROGRAMS

Liquid and Gas system Operations

(Activity No. AR $051005 \mathrm{~K}$; 189 NO. ONL-WNOl)

AN EVALUATION OF THE LOW-LEVEL WASTE TREATMENT PLANT

AT OAK RIDGE NATIONAL IABORATORY, AND SUGGESTED

CHANGES IN THE DESIGN AND OPERATION

J. M. Chilton

Date Published - March 1980
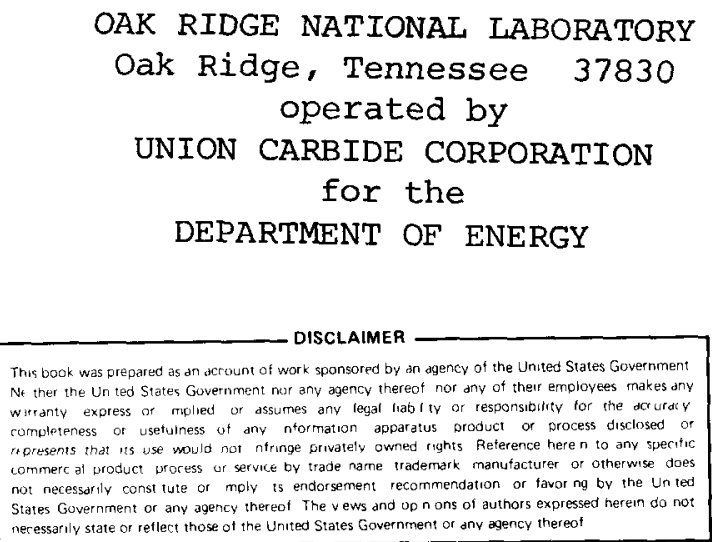
. 
TABLE OF CONTENTS

$\underline{\text { Page }}$

Abstract . . . . . . . . . . . . . . . . . . . . 1

1. Introduction . . . . . . . . . . . . . . . . . . 2

1.1 Development of the SP-IX Process . . . . . . . . . . 2

1.2 Description of the LLWT Plant . . . . . . . . . . . 4

1.3 Current Operation of the LIWT Plant. . . . . . . . . . 5

2. Analysis of Operation . . . . . . . . . . . . . . . 7

2.1 Composition of the Waste Stream . . . . . . . . . . . 8

2.2 Head-End Treatment . . . . . . . . . . . . . . 8

2.3 Precipitator - Clarifier - Filter . . . . . . . . . 9

2.4 Ion Exchange . . . . . . . . . . . . . . . . . 9

2.4.1 Description of Resin . . . . . . . . . . . . 9

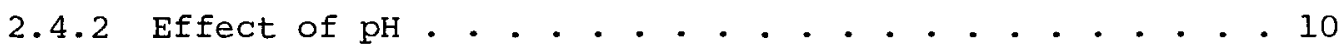

2.4.3 Capacity and Distribution Coefficients....... . 11

2.4.4 Resin Stability ............... . 12

2.4.5 Channeling of the Beds............. 13

2.4 .6 Regeneration . . . . . . . . . . . . . 14

2.5 Radioactivity Detectors . . . . . . . . . . . 15

2.6 Decontamination Efficiency . . . . . . . . . . . 15

3. Recommendations . . . . . . . . . . . . . . . . . 16

3.1 Equipment . . . . . . . . . . . . . . . . 16

3.2 Operation . . . . . . . . . . . . . . . . . . 17

4. Acknowledgments .. . . . . . . . . . . . . . . 18

5. References ...................... 18

6. Appendix ........................ . . 19 
AN EVALUATION OF THE LOW-LEVEL WASTE TREATMENT PLANT AT OAK RIDGE NATIONAL LABORATORY, AND SUGGESTED CHANGES IN THE DESIGN AND OPERATION

\author{
J. M. Chilton
}

\title{
ABSTRACT
}

The operation of the Low-Level waste Treatment (LLWT) Plant was monitored critically for one month for two reasons: to determine the cause of infrequent periods when the precipitation-filtration step failed to remove the normal amount of hardness and to suggest any changes that might improve the operation. All steps in the process were evaluated to determine whether modifications would be beneficial.

During the experimental period, each of the three resin beds loaded with Duolite CS-100 resin was taken through one loading-elution cycle. Numerous samples were taken and analyzed in addition to the routine analytical data. The primary radioactivity in this waste is ${ }^{90} \mathrm{Sr}$ and ${ }^{137} \mathrm{Cs}$, and, under optimum conditions, the plant discharges about $0.015 \mathrm{dpm} / \mathrm{ml}$ of $90 \mathrm{Sr}$ and $0.06 \mathrm{dpm} / \mathrm{ml}$ of $137 \mathrm{Cs}$. Laboratory studies measured the capacity of the CS-100 resin for these elements under a variety of conditions.

Although no strontium breakthrough was noted, the results showed that cesium broke through each of the beds after the passage of about 550 bed volumes. Development work for this process had indicated a useful capacity of about 2000 bed volumes, however, and the plant has routinely operated using this value. Samples of resin taken from each of the beds showed that the static volumetric distribution coefficient (DC) for cesium had dropped from 3900 for new resin to about 475 for used resin. Also, the DC for strontium dropped from 20,000 to about 5500 . The optimum loading of cesium was found at $\mathrm{pH}$ 11.9. Because of insufficient data, no clear-cut cause could be established for the occasional incomplete calcium precipitation. Even using exhausted resin, however, the exit stream is below the permissible concentration for all radionuclides in public streams.

Recommendations from this study are (1) immediate replacement of all three resin columns, (2) relocation of the $\mathrm{pH}-$ sensing electrode in the precipitation step, (3) use of a more dilute caustic solution for regeneration, (4) institution of a sampling routine to determine more promptly the breakthrough of cesium from the resin, and (5) relocation and possible modification of the gamma detector in the exit stream. Other 
topics related to the plant operation and suggested for further study are (1) more thorough chemical analyses of the feed stream during periods of incomplete calcium precipitation, (2) detailed recording of the cesium loading of one column to determine the pattern of degeneration, (3) determination of possible channeling in the beds by appropriate sampling of the resin at various positions, (4) using new resin, determination of whether or not the gamma detector on the exterior of the bed will follow a loading band, and (5) possible modifications in the elution procedure.

\section{INTRODUCTION}

Since March 1976, the low-level aqueous waste collected from various locations at Oak Ridge National Laboratory (ORNL) has been processed in a plant that uses a scavenging-precipitation-ion exchange (SP-IX) flow sheet developed at ORNL. ${ }^{1-5}$ Before March, waste was treated by a limesoda-clay process, which removed a fraction of the radionuclides (e.g., $62 \%$ of the ${ }^{90} \mathrm{Sr}$ ) but necessitated further dilution in white oak creek and the Clinch River to meet environmental standards. At the request of the Operations Division, a detailed study of the plant's operation was carried out in February and March of 1978. The primary objective was to suggest changes in the plant design or operational procedure that might improve performance; this objective was accomplished when several recommendations were referred to the Operations Division. A secondary objective, which was only partially attained, was to discover the cause of brief, infrequent periods when the precipitation step performed less satisfactorily than normal.

\subsection{Development of the SP-IX Process}

As early as 1961 laboratory-scale work began in order to find a method of decontaminating low-level waste that was more efficient than the limesoda process then in use. Several types of ion exchange resin were evaluated, and a flow sheet was developed using Duolite $\mathrm{CS}-100$ resin, ${ }^{1}$ which is a weak-acid carboxylic-phenolic resin with a high cesium and strontium 
capacity. This resin is highly resistant to swelling and shrinking and can be regenerated with $0.5 \mathrm{MNO}_{3}$.

The feed is made $0.01 \mathrm{M}$ in $\mathrm{NaOH}$ and filtered before going to the ion exchange column. This step precipitates most of the calcium and magnesium and carries down dirt, algae, and a substantial part of the radioactivity; it also raises the $\mathrm{pH}$ to the optimum level for cesium loading on the sodiumform resin.

The procedure was demonstrated with a $1.25-$ by $15.25-\mathrm{cm}$ column, using a synthetic feed containing ${ }^{137} \mathrm{Cs},{ }^{85} \mathrm{Sr}$, and ${ }^{141} \mathrm{Ce}$. Cesium breakthrough (18) occurred at 1600 to 1900 bed volumes. Extrapolation of these data to $50 \%$ breakthrough yielded a volumetric distribution coefficient (DC) of 3200 to 3800 .

It was noted that nitric acid greater than $1 \underline{M}$ will attack the resin, as will $0.5 \underline{M}$ acid after two months of contact. In this case, 18 cesium breakthrough occurred at 1150 bed volumes, though the extrapolation to $50 \%$ breakthrough was essentially the same.

The process was then scaled up to a semipilot demonstration. Some changes were made and a 3-liter bed of resin was used. Sodium hydroxide was added to adjust the $\mathrm{pH}$ to 11.7 , and $5 \mathrm{ppm}$ iron as ferrous sulfate was added simultaneously. This improved precipitation step removed 1 to $10 \%$ of the cesium, 30 to $70 \%$ of the strontium, 70 to $90 \%$ of the ruthenium and cobalt, and more than $70 \%$ of the rare earths. Phosphate in the feed increased the number of water-hardness ions that remained in solution after precipitation; $3 \mathrm{ppm}$ phosphate left 60 to $70 \mathrm{ppm} \mathrm{CaCO}_{3}$, while 1 to $3 \mathrm{ppm}$ $\mathrm{CaCO}_{3}$ were left when no phosphate was present. The addition of sodium carbonate during the head-end treatment overcame phosphate's effect, but raising the total sodium concentration from 0.01 M to 0.02 M reduced the cesium breakthrough point from 1800 to 1000 bed volumes. Strontium breakthrough began at about 3000 bed volumes.

The use of additional resins with the Duolite CS-100 was investigated. A bed of Amberlite IRC-50 could be used before the CS-100 to remove calcium, magnesium, and strontium, and thus to extend the capacity of the CS-100 resin. An anion exchange resin in the hydroxide form could remove, to 
below detection limits, any remaining ruthenium and cobalt passing through the cation bed.

The process was next demonstrated on a pilot-plant scale, using actual ORNL low-level wastewater as feed. ${ }^{3}$ Eleven cycles of the loading-elutionregeneration were carried out on a bed of 106 liters of resin; this bed had a height/diameter ratio of $8.25: 1$ and the flow rate proposed for a fullscale plant ( 37.5 liters/min through the $25-\mathrm{cm}$ column). Three runs were also made in a column with a ratio of $2: 1$, using the same volume of resin. No differences could be attributed to the different geometries.

Much of the work in this pilot-plant study centered on improving the precipitation-filtration step. A process used in municipal water-supply plants and composed of a flash mixer, a coagulation tank, a sludge blanket clarifier, and an anthracite bed filter was modified, causing a reduction of hardness in the clarifier effluent from 8 to $14 \mathrm{ppm}$ to 1 to $3 \mathrm{ppm}$.

Studies of the effect of hexametaphosphate in the feed indicated no adverse effects up to $2 \mathrm{ppm}$, and in the range of 2 to $4 \mathrm{ppm}$ the addition of $0.005 \mathrm{M} \mathrm{Na}_{2} \mathrm{CO}_{3}$ ensured adequate hardness removal. As previously indicated, however, the additional sodium in the feed reduced the effective capacity of the ion exchange column by $50 \%$.

\subsection{Description of the LIWT Plant}

The total treatment plant consists of: (1) the equalization basin; (2) the feed system, Building 3518; (3) process equipment, Building 3544;

(4) the sludge disposal basin; and (5) radioactive-waste transfer piping. The first three components are located in the main ORNL area, the sludge disposal basin is located at Burial Ground No. 5 about $1.0 \mathrm{~km}$ south of the processing plant, and the waste transfer piping connects the processing plant with the disposal basin and the ORNL Intermediate-Level Waste System.

The equalization basin has existed for a number of years and has a capacity of $3.8 \times 10^{6}$ liters of low-level waste (<1.0 $\mu \mathrm{Ci} / 1$ iter), which is essentially ${ }^{90} \mathrm{Sr}$ and ${ }^{137} \mathrm{Cs}$. Smaller quantities of ${ }^{60} \mathrm{Co}$ and ${ }^{154} \mathrm{Eu}$ are sometimes present. 
Feed is pumped continuously from the basin through pipes, pumps, and valves located in Building 3518. Only minor modifications were made to this equipment to convert it from the previously used lime-soda process. Feed is pumped at a selected rate, usually between 175 and 375 liters/min, into the processing plant in Building 3544 .

This building is divided into a control room, a chemical makeup area, and a shielded area containing regeneration-solution tanks, three ion exchange columns, an evaporator, a concentrated-waste tank, an acid offgas scrubber, and pumps. The head-end treatment equipment, the sludge holdup and transfer system, and a concrete clearwell about $7 \times 7 \times 2 \mathrm{~m}$ are located on a concrete pad outside the building.

The sludge that is generated in the precipitator-clarifier is periodically pumped to the sludge disposal basin as a slurry containing 2 to 4 wt $\%$ solids.

The line connecting the process building to the sludge disposal basin is constructed of 2-in. schedule 80 , unplasticized PVC pipe and is laid underground. The concentrated liquid waste from ion exchange regeneration, evaporation, and neutralization is pumped through an underground pipeline constructed of $1-\frac{1}{2}-$ in. schedule 40 , type $304 \mathrm{~L}$ stainless steel to the existing intermediate-level waste collection system.

\subsection{Current Operation of the LLWT Plant}

The LLWT Plant has been in continuous operation for about two years at an average flow rate of $300 \mathrm{liters} / \mathrm{min}$. Occasionally, feed has been processed as fast as 565 liters/min. At no time has the plant effluent exceeded the maximum permissible concentration for water in public streams $\left(M_{W}\right)$ (Appendix, Table 2). The plant is designed for a maximum flow of 750 liters/min but has never operated at this rate.

The feed from the equalization basin is continually mixed with concentrated sodium hydroxide solution to give a $\mathrm{pH}$ of 11.8 and with a copperas $\left(\mathrm{FeSO}_{4}\right.$ ) solution to give $5 \mathrm{ppm}$ iron. The hydroxide addition rate is controlled by an electrode downstream from the addition point in the feed. The ferrous 
solution rate is controlled by the setting on the feed pump. The feed then flows through a static pipe-mixer. Coagulation of the precipitate into larger particles occurs in the flocculator section of the precipitator-clarifier, where the mixture is gently agitated as it flows down to the bottom. The floc enters the bottom of the clarifier section, where separation is achieved by upflow of the mixture through a sludge blanket, which consists of fluidized particles that trap the floc and continue the precipitation reactions by crystal growth. These particles agglomerate and settle to form a slurry in the bottom of the vessel. This action scavenges radionuclides, dirt particles, and algae, as well as most of the hardness, from the waste stream.

The slurry is periodically pumped to an agitated 23,000-1iter sludge holding tank and then to the sludge disposal basin, as necessary. This step removes from one-half to two-thirds of the total radioactivity in the stream. The proper operation of the clarifier section is monitored by turbidity analyses of samples taken at appropriate points in the stream.

The effluent from the clarifier overflows to a 25,000-liter surge tank and then is pumped through one of two pressure-type polishing filters containing a bed of 0.6 to $0.8-\mathrm{mm}$ anthracite. When pressure drop increases 5 to 6 psi, the flow is switched to the other bed and the first one is backwashed. Backwashing is done at 2000 liters $/ \mathrm{min}$ for $10 \mathrm{~min}$ with water from the clearwell. The bed is then rewashed at $650 \mathrm{liters} / \mathrm{min}$ for $3 \mathrm{~min}$, after which the wash solution is pumped back to the equalization basin.

From the filter, the stream, which now usually has less than 5 ppm hardness, passes downflow through one or more of three ion exchange columns containing 1275 liters of sodium-form Duolite CS-100 resin. The beds are used consecutively; a switch is made after the passage of about 2000 bed volumes of feed. The maximum flow rate through a bed is 380 liters/min, but two beds may be operated simultaneously, in parallel. A movable betagamma probe is mounted on the exterior of each column. In the pilot-plant development of the process, it was found that such a probe could be used to follow a band of maximum activity from top to bottom as the column was used and thus to predict breakthrough of radionuclides. Since the readings from these probes in plant operation have never been of value, their use has been discontinued. 
To regenerate a resin bed, the column is eluted upflow with two batches (five bed volumes each) of $0.50 \mathrm{M}$ nitric acid. The first batch removes most of the radioactivity and hardness and is then concentrated by evaporation, neutralized with sodium hydroxide, and sent to the Intermediate-Level Waste Treatment Plant. The second batch is stored and used as the first batch for the next elution. After a water rinse, the resin is reconverted to a sodium form by passing 20 bed volumes of $0.1 \mathrm{M} \mathrm{NaOH}$ upflow through the bed. The caustic and water washes are sent back to the equalization basin.

After leaving the ion exchange bed, the stream passes over a beta-gamma probe and into the first compartment of the clearwell. The readings from this monitor apparently cannot be correleated with any variable in the process and are therefore generally ignored.

The clearwell, which contains 80,000 liters, is divided into two sections by an overflow weir. Water in the first section, which holds twothirds of the volume, backwashes the filters and makes up the $0.1 \mathrm{M} \mathrm{NaOH}$ for resin regeneration. At the weir, where a pH electrode continuously measures the $\mathrm{pH}$, sulfuric acid is added to reduce the $\mathrm{pH}$ to 7.0 . The waste then flows into white oak creek.

\section{ANALYSIS OF OPERATION}

During the four-week experimental period, the plant was operated in the routine manner. Along with the usual water samples, however, additional samples were taken from several points in the stream. Also, samples of resin were removed from each bed and subjected to various tests in the laboratory. The beta-gamma monitors on the exterior of the ion exchange columns scanned them every $8 \mathrm{hr}$, and the results were recorded. During one period, which occurred several months after the experimental run, a malfunction was noted in which excessive hardness was passing through the scavenger-precipitator, and samples of the plant feed (from the equalization basin) were then taken and thoroughly analyzed for ionic constituents. 


\subsection{Composition of the Waste stream}

The compositions of the waste stream in previous years, during the experimental program, and during the "high-hardness" period, can be compared (Appendix, Table 1). Although the compositions are for the most part similar, some differences can be noted that possibly influence the plant's behavior.

1. The $\mathrm{pH}$ (and the total alkalinity) levels are higher than they were previously. The relation between total hardness, $\mathrm{pH}$, and carbonate-bicarbonate content is shown in the Appendix, Fig. 1; no variable in the plant operation could be attributed to this relationship. It can be assumed that the wastes entering the basin do not contain as much free acid as they formerly did.

2. The total solids content is somewhat higher than it was formerly and was especially high during the "high-hardness" period. Most of this increase was due to nitrate salts. Whether or not this increase has any influence on the poor performance of the precipitator-clarifier is uncertain.

3. The phosphate level was below $1.0 \mathrm{ppm}$ during the experimental run but was $1.6 \mathrm{ppm}$ during the "high-hardness" period. The laboratory development studies indicated that hardness precipitation would begin to be incomplete at levels above $1.0 \mathrm{ppm}$ but that about $2.5 \mathrm{ppm}$ phosphate was required to leave $50 \mathrm{ppm}$ hardness in solution. ${ }^{2}$ The addition of $\mathrm{Na}_{2} \mathrm{CO}_{3}$ in the head-end treatment, though effective at ensuring adequate hardness removal in the laboratory studies, was unsuccessful in the plant. Further experimental work will be required to clarify this relationship.

\subsection{Head-End Treatment}

During the experimental program, no changes were made in the routine head-end treatment of the feed. Ferrous sulfate was added to give 5 ppm iron, and concentrated sodium hydroxide solution was added at a rate controlled by a pH electrode set at pH 11.8 and located immediately downstream from the mixing point. A detailed description of this part of the process is given in the pilot-plant development report. ${ }^{3}$

The caustic addition serves two purposes: first, to precipitate most of the hardness along with some of the radioactivity, and second, to raise the $\mathrm{pH}$ to the optimum level for cesium loading on the CS-100 resin. In 
this study, laboratory measurements showed that the DC for cesium was almost constant between $\mathrm{pH} 11.7$ and 11.9 but decreased at higher and lower values. During this experimental period, the $\mathrm{pH}$ of the effluent from the resin beds (L-4) ranged from 11.1 to 11.6 , with an average of 11.3. These values can be assumed for the feed solution to the columns $(L-3)$. It is suggested that the pH-controlling electrode be moved in order to maintain the L-3 stream at $\mathrm{pH} 11.85$ or that a second caustic addition be made at this point.

\subsection{Precipitator - Clarifier - Filter}

During the experimental run, no attempt was made to modify anything in this section of the plant. Operation of the sludge blanket, as shown by turbidity samples taken at appropriate points, was normal during this period. On the later occasion of the hardness breakthrough, the samples still indicated satisfactory performance. If a malfunction should exist in this part of the plant, it must be detected and analyzed by an engineering group familiar with the equipment.

\subsection{Ion Exchange}

The heart of this process is the use of an ion exchange resin that removes the cesium and strontium activity remaining after the precipitationfiltration. During this program, column feed values ranged from 7 to 30 $\mathrm{dpm} / \mathrm{ml}$ for ${ }^{90} \mathrm{Sr}$ and from 5.2 to $11.0 \mathrm{dpm} / \mathrm{ml}$ for ${ }^{137} \mathrm{Cs}$. The ion exchange step satisfactorily removed the strontium to less than $0.06 \mathrm{dpm} / \mathrm{ml}$ but removed cesium to less than $1 \mathrm{dpm} / \mathrm{ml}$ only during the first 500 to 600 bed volumes of feed during each cycle. These strontium and cesium values are shown graphically in the Appendix (Figs. 2 and 3, respectively), and the numerical data are presented there as well (Table 2).

\subsubsection{Description of resin}

The most satisfactory ion exchange resin for loading cesium in the presence of relatively large amounts of sodium is Duolite CS-100. A detailed 
tabulation of the properties of this resin, which contains both carboxylic and phenolic reaction groups, is provided by the manufacturer, Diamond Shamrock Chemical company. ${ }^{6}$ In the sodium form in 0.01 M sodium hydroxide, all divalent ions (calcium, magnesium, strontium, etc.) will load strongly on both reaction sites. Cesium will load on the phenolic groups, though not as strongly. This resin can be regenerated with 0.5 M nitric acid, which is an advantage in the selection of materials of construction. The resin is furnished as porous granules of 0.3 to $1.3 \mathrm{~mm}$, and its total ionic capacity is a minimum of 1.0 equiv/liter.

Another radionuclide present in the waste stream is ${ }^{60} \mathrm{Co}$, a fraction of which does not behave as a divalent cation. From 15 to $40 \%$ of the ${ }^{60} \mathrm{Co}$ was removed in the precipitation step, but essentially none was removed by the resin (Appendix, Fig. 2). Previous development work showed that ${ }^{60}$ Co could be loaded on an anion resin in the hydroxide form. ${ }^{2}$

\section{4 .2 Effect of $\mathrm{pH}$}

The sorption of cesium ions on the sodium-form CS-100 resin occurs only at $\mathrm{pH}$ levels high enough to ionize the phenolic groups. In the initial development of this process, values ranging from $\mathrm{pH} 11.7$ to 12.0 were used by different investigators, and all were apparently successful. To determine the optimum $\mathrm{pH}$, static DFs were established for cesium on unused resin as a function of $\mathrm{pH}$, with a constant sodium content of $0.01 \mathrm{M}$. Normalizing the value at $\mathrm{pH} 11.9$, the following results were obtained:

\begin{tabular}{|c|c|}
\hline $\mathrm{pH}$ & $\begin{array}{l}D C \\
(8) \\
\end{array}$ \\
\hline 11.5 & 60 \\
\hline 11.6 & 83 \\
\hline 11.7 & 87 \\
\hline 11.8 & 90 \\
\hline 11.9 & 100 \\
\hline 12.0 & 94 \\
\hline 12.1 & 84 \\
\hline
\end{tabular}

The DCs decrease with increasing sodium concentration in the feed when held at a constant $\mathrm{pH}$, but this factor has not been evaluated quantitatively. ${ }^{2}$ 
During the experimental run, the $\mathrm{NaOH}$ that was added resulted in a sodium concentration of 0.006 to $0.008 \mathrm{M}$. The sodium content in the plant feed was $0.003 \underline{M}$, so the total was 0.009 to $0.011 \underline{M}$, which is probably not excessive.

\subsubsection{Capacity and distribution coefficients}

The manufacturer of the Duolite CS-100 resin states that the total ionic capacity is at least 1.0 equiv/liter, a value that was confirmed in the laboratory, using dilute calcium solutions and new resin. For a specific set of conditions, however, there is a constant ratio between the amount of an ion sorbed on a specified amount of resin and the ionic concentration in the solution at equilibrium. For dilute solutions of an ion, this fact will limit the volume of feed before the total capacity of the bed is reached. If the $\mathrm{DF}$ is expressed in volume units, breakthrough will occur when the number of bed volumes of feed equals the DC. In practice, true equilibrium in flowing streams is never reached and breakthrough occurs at a lower feed volume. In some cases it is useful to know whether the resin capacity or the DC of the ion in question limits the loading. Mathematically, it can be shown that at saturation, bed volumes of feed $x$ ppm concentration $=1000 \mathrm{x}$ equivalent weight $\mathrm{x}$ capacity per liter. The values to the right of the equal sign are constants, so there is a maximum value of the average ppm concentration above which saturation will limit the loading and below which the DC will determine the limit. When the CS-100 resin is used, the concentration for the calcium ion is about $2.5 \mathrm{ppm}^{\mathrm{CaCO}_{3}}$. The weight concentration for the cesium ion is so small that the DC is the controlling factor, and for new resin, the effective DC for cesium under these conditions is 2000 to 2500. Therefore, cesium breakthrough will begin when about 2000 bed volumes of feed have been passed. The calcium in the feed, however, which has a higher DC (by a factor of about 6) will saturate reaction sites and thus decrease the effective volume of the resin bed. A calculation of the amount of feed that can be loaded for maximum cesium retention must therefore consider both the DC for the cesium and the total amount of hardness loaded for the bed. For this plant, which has a bed volume of 1250 liters, an equation such as the following could be used for new resin: 
Maximum loading (liters) $=2000\left(1250-2.0 \times 10^{-5} \Sigma\right.$ Iiters passed $x$ ppm hardness).

\section{4 .4 Resin stability}

In the development work for this process, the limiting number of bed volumes of feed that could be processed was variously reported as 1600 to $1900,{ }^{1} 1500$ to $2000,{ }^{2} 2000,3,4$ and more than $2000 .^{5}$ On the basis of this prior experience, the plant routinely passes about 2000 bed volumes per cycle. During the experimental program, analysis of the daily ion exchange effluent samples ( $L-4)$ showed that cesium breakthrough began at 500 to 600 bed volumes, as is shown in the Appendix (Figs. 3A-C). This was the 39th loading-elution-regenerating cycle for each bed. The obvious explanation is that the DC of the resin for the cesium had decreased from the 2000 value to a value of about 550. To confirm this, small samples of resin were removed from each resin bed and the static DCs for cesium and strontium were measured in the laboratory and their values compared with those obtained for new resin under the same conditions. On new resin, the strontium DC value was about 20,000, and the cesium DC value was about 3900 . Since the previous experimental development work indicated a useful capacity of about 2000 bed volumes for cesium loading, the DCs under these conditions are about one-half of the equilibrium values. The static DC for cesium on the used resin samples averaged 546 , or $14 \%$ of the new resin, and the static DC for strontium averaged 5500, or $27.5 \%$ of the original. Although these values are not precise because of the error involved in accurately measuring small volumes of resin, the resin unquestionably had degenerated. It is known that all resins will deteriorate with continued use, so an effort was made to find information on this particlar one. The manufacturer had no data on this subject (private communication). In the prior development work, a maximum of 11 runs was made on one bed, and no decrease in loading was noted.

Carboxylic resins are more sensitive to radiation damage than are sulfonic resins; a radiation dose of about $10^{8} \mathrm{rad}$, compared with $10^{9} \mathrm{rad}$, is required for a significant loss in capacity. 7 Liberal estimates of the maximum dose received by these beds indicate an upper limit of about $10^{4} \mathrm{rad}$. 
Additionally, DCs of resin samples taken from the tops of the columns, which receive the most radiation, were not significantly different from those of samples taken from the bottom.

During the previous developmental programs, evidence showed that this resin is sensitive to nitric acid concentrations greater than $1.0 \mathrm{M}^{1}$ For this reason, elaborate precautions are taken to make the elution acid exactly $0.5 \underline{M}$ and to leave it in the beds no longer than necessary.

In laboratory studies duplicating the elution-regeneration cycle, it was noted that the greatest appearance of a "color throw," or a brown color in the effluent, occurred during the hydroxide regeneration step rather than during the acid elution step. Samples of new resin were allowed to stand in solutions of 0.5 M nitric acid, 0.01 M sodium hydroxide, and 0.1 M sodium hydroxide. The samples were removed after $90 \mathrm{hr}$ and after 19 days, and the cesium and strontium DCs, given as percentages, were determined and compared with those for untreated resin.

\begin{tabular}{|c|c|c|c|}
\hline & $0.5 \underline{\mathrm{M}} \mathrm{HNO}_{3}$ & $0.01 M \mathrm{MaOH}$ & $0.1 \underline{\mathrm{M}} \mathrm{NaOH}$ \\
\hline \multicolumn{4}{|l|}{ Cesium } \\
\hline $90 \mathrm{hr}$ & 88 & 104 & 51 \\
\hline 19 days & 85 & 88 & 54 \\
\hline \multicolumn{4}{|l|}{ strontium } \\
\hline $90 \mathrm{hr}$ & 84 & 101 & 44 \\
\hline 19 days & 106 & 89 & 78 \\
\hline
\end{tabular}

These results indicate that the caustic used for regeneration $(0.1 \mathrm{M})$ is more deleterious than the nitric acid. Further laboratory work will be required to develop the optimum elution-regeneration cycle.

\subsubsection{Channeling of the beds}

The CS-100 resin is composed of granules, not spherical particles, and so tends to agglomerate with downflow of the feed. In severe cases, this could lead to channeling and thus cause a lowered bed capacity. Resin samples were withdrawn from various positions in each bed - some after loading and some after regeneration. These samples were analyzed for ionic 
constituents by spectrographic and neutron-activation methods. The results were erratic, and it was impossible to draw definite conclusions. The level of the divalent and trivalent ions, however, tended to be higher in samples from the bottom of the columns than from elsewhere, indicating channel flow in either the loading or the elution, or both. During the elution cycle of one column, the behavior of the resin was visually observed through a window located midway down the side of the column. During the upflow of the nitric acid the resin particles were fluidized, but how far into the column they were fluidized could not be determined.

\subsubsection{Regeneration}

As stated before, a bed is eluted and regenerated at the end of each cycle by backwashing with ten bed volumes of 0.5 M nitric acid followed by 20 bed volumes of $0.1 \mathrm{M}$ sodium hydroxide. In the three elutions carried out in the experimental runs, the acid elution removed the loaded radioactivity satisfactorily; the activity in the ninth or tenth bed volume was less than $1 \%$ of the peak activity. It can be assumed that the regeneration to the sodium form was complete since a 1008 excess of sodium hydroxide was used. The following levels of activity, given in $\mathrm{dpm} / \mathrm{ml}$, occurred in the second and eighth bed volumes:

\section{Elution Volume}

$90 \mathrm{Sr}$

$$
2 d
$$

8 th

$137 \mathrm{Cs}$

$$
2 d
$$

8 th

\begin{tabular}{ccc}
\multicolumn{4}{c}{ Column } \\
\hline$\underline{A}$ & $\underline{B}$ & $\underline{C}$
\end{tabular}

$$
7.36 \times 10^{3}
$$

676

$$
2.43 \times 10^{3}
$$$$
16.6
$$

$2.04 \times 10^{4}$

247

$1.09 \times 10^{3}$

18.6
$2.89 \times 10^{4}$

251 


\section{5 Radioactivity Detectors}

A beta-gamma probe that can be moved to any desired elevation is located on the exterior wall of each resin column in the plant. The total counts are recorded on a strip chart in the control room. In the pilotplant development of this process, a band of maximum activity moved from the top to the bottom of the resin bed during the loading cycle. ${ }^{3}$ It was thought that the cesium breakthrough point could be anticipated by following the movement of such a band in the plant beds. After the plant began operation, however, all attempts to use these detectors for this purpose were unsuccessful and were abandoned. During the experimental runs, readings were taken every $8 \mathrm{hr}$ at $30-\mathrm{cm}$ intervals on the column in use. Up to the time of the cesium breakthrough (500 bed volumes), values from the lower half. of the beds increased gradually; no changes were sharp enough to be of value in predicting breakthrough. Data from each bed are shown graphically in the Appendix [Figs. 3(a)-(c)]. Another beta-gamma probe, which also records on a chart in the control room, is located in the resin-column exit stream leading to the clearwell. Small fluctuations in this probe's readings were noted from time to time, but they could not be correlated with any other variable in the operation. With certain changes in the design and location of these probes, they may prove valuable in plant operation (Sect. 3).

\subsection{Decontamination Efficiency}

This plant is specifically designed for removing two isotopes, ${ }^{90} \mathrm{Sr}$ and ${ }^{137} \mathrm{Cs}$. When the ion exchange columns perform correctly, the effluent stream will contain less than $0.1 \mathrm{dpm} / \mathrm{ml}$ for each of these radionuclides. This value is essentially independent of the concentration in the inlet stream; hence, results expressed as decontamination factors are not meaningful. It is perhaps more meaningful to express concentrations in terms of fractions of the $\mathrm{MPC}_{\mathrm{w}} \cdot{ }^{8}$ The ${ }^{90} \mathrm{Sr}$ content of the plant effluent never exceeded $9 \%$ and averaged $4 \%$ of the $\mathrm{MPC}_{\mathrm{W}}$ during the experimental runs (Appendix, Table 2). The ${ }^{137}$ Cs level varied from $0.13 \%$ of the $\mathrm{MPC}_{\mathrm{w}}$ at the beginning of each cycle to $32 \%$ of the $M P C_{w}$ at the end of the C-column run. 
Two other radionuclides, ${ }^{60} \mathrm{Co}$ and ${ }^{154} \mathrm{Eu}$, can usually be detected in these streams. During the experimental runs, the cobalt and europium levels in the plant feed never exceeded $1.4 \%$ of the $\mathrm{MPC}_{\mathrm{w}}$, and the europium concentration in the plant effluent never exceeded $1 \%$ of the $\mathrm{MPC}_{\mathrm{W}} \cdot$ The precipitation-filtration step removed 13 to $38 \%$ of the cobalt, but the resin columns did not remove any more. Previous investigations have shown that some of the cobalt is in an anionic complex. Decontamination levels throughout the plant are shown in the Appendix (Table 2 and Fig. 2).

\section{RECOMMENDATIONS}

As a result of this experimental period of plant operation, several recommendations have been made to the Operations Division. Some of these suggestions are semiexperimental, and their worth would have to be evaluated after implementing them.

\subsection{Equipment}

To date, the cause of brief, infrequent periods when the level of hardness passing through the clarifier is unusually high has not been discovered. If further analyses of the chemistry of the plant feed cannot pinpoint the cause, an engineering group should inspect the operation of the precipitator, sludge blanket, clarifier, and filter.

As in the pilot-plant work, a high-activity band could probably be followed down a column during cesium loading in the plant. A shield could be fitted around the gamma detectors so that only a collimated beam coming directly out of the resin bed would be registered. If this does not provide enough improvement, a filter circuit or a gamma-pulse-height analyzer could be used to detect only the 0.662-MeV gamma energy associated with the ${ }^{137} \mathrm{Cs}$.

Actually, ${ }^{137} \mathrm{Cs}$ which has a 30-year half-life, undergoes beta decay and becomes metastable ${ }^{137} \mathrm{Ba}$, which emits the $0.662 \mathrm{MeV}$ gamma ray with a 2.6-min half-life. The CS-100 resin loads all divalent ions (including 
barium) very strongly even when the cesium is not loading. Therefore, the effluent from the resin columns will show no $0.662-\mathrm{MeV}$ activity immediately, regardless of the ${ }^{137}$ Cs level. This activity will grow in with the 2.6min half-life. For this reason, the gamma detector in the L-4 stream should be relocated so that a $25-$ to $30-\mathrm{min}$ delay occurs after the stream leaves the resin bed.

\subsection{Operation}

In the precipitation step, sodium hydroxide is continuously added to the flowing feed stream as a concentrated (50\%) solution. This has two disadvantages: the pump operates near its lowest rate, making precise control difficult, and the feed line can become blocked by precipitation in cold weather. The $50 \%$ solution should be diluted to about $20 \%$.

As stated before, the optimum $\mathrm{pH}$ for cesium loading is about 11.9 . During the experimental runs, the $\mathrm{pH}$ of the feed entering the columns was only about 11.3. This decrease in basicity is due to the loss of hydroxide in the precipitation step. A pH electrode should be put in the L-3 stream, and either the original precipitation stream or sodium hydroxide addition in $\mathrm{L}-3$ should be controlled to keep the $\mathrm{pH}$ at 11.85 .

The current mode of operation is to pass 2000 bed volumes of feed through each bed before switching to another bed. Because additional information about the true capacity of the beds for cesium as a function of age, number of cycles, etc., is lacking, the 2000 bed volumes should be changed to 2000 "unloaded bed volumes." The volume of the bed that is "loaded" (i.e., saturated with hardness ions) can be calculated for each run from the hardness analyses on the L-3 stream. Thus, for this resin: resin loaded (liters) $=2 \times 10^{-5} \sum$ liters fed $\mathrm{x}$ ppm hardness.

The plant effluent ( $\mathrm{L}-4$ ) should be sampled at least once a day, and preferably once every $8 \mathrm{hr}$, and its ${ }^{137} \mathrm{Cs}$ content should be promptly analyzed. When this value exceeds $1.0 \mathrm{dpm} / \mathrm{ml}$, a new column should be started. 
Laboratory-scale work should be continued in order to attempt to resolve remaining unknowns. Chief among these are the DCs and capacities of new resin and the factors that cause them to deteriorate. Further work might be done to evaluate the possibility of using other resins in an alternate flow sheet.

\section{ACKNOWLEDGMENTS}

The author is grateful for the cooperation afforded him during this work by all personnel in the Low-Level waste Treatment Plant - especially Mr. Larry Lasher. Appreciation is also expressed to Mr. Tom Scott of the Low-Level Analytical Laboratory.

\section{REFERENCES}

1. R. R. Holcomb and J. T. Roberts, Low Level Waste Treatment by Ion Exchange, Part II: Use of a Weak Acid, Carboxylic-Phenolic Ion Exchange Resin, ORNL/TM-5 (Sept. 25, 1961).

2. R. R. Holcomb, Low-Radioactivity-Level Waste Treatment, Part I: Laboratory Development of a Scavenging-Precipitation Ion-Exchange Process for Decontamination of Process Water Wastes, ORNL-3322 (July 10, 1963).

3. R. E. Brooksbank, F. N. Browder, R. R. Holcomb, and W. R. Whitson, LowRadioactivity-Level Waste Treatment, Part II: Pilot Plant Demonstration of the Removal of Activity from Low-Level Process Wastes by a Scavenging-Precipitation Ion-Exchange Process, ORNL-3349 (May 13, 1963).

4. F. E. Harrington and J. M. Holmes, Design Study - New ORNL Process Waste Treatment Plant, ORNL/TM-3522 Rev. (Aug. 14, 1972).

5. R. J. Braatz and R. A. Robinson, Safety Analysis Report - Building 3544 Process Waste Treatment Plant, ORNL/TM-5444 (June 1976).

6. Diamond Shamrock Chemical Company, Duolite CS-100, Duolite Tech Sheet 100 (January 1974).

7. R. E. Wedemeyer, The Stability of Ion Exchange Resins to X-rays, Ph.D. Thesis, Vanderbilt University, Nashville, Tenn. (1953).

8. 10 CFR Pt. $0.735-1$. 
6. APPENDIX 
Table 1. Analyses of ORNL low-level waste

(Values are in ppm unless otherwise indicated)

\begin{tabular}{|c|c|c|c|}
\hline & $\begin{array}{l}\text { ORNL/TM-5444, } \\
\text { June } 1976\end{array}$ & $\begin{array}{c}\text { Experimental run, } \\
\text { Feb.-Mar. } 1978\end{array}$ & July 1978 \\
\hline Total hardness ${ }^{a}$ & $100-120$ & $38-160$ & 149 \\
\hline Calcium hardness ${ }^{a}$ & $60-85$ & & \\
\hline Total alkalinity ${ }^{a}$ & $80-95$ & $108-298$ & 280 \\
\hline Calcium & $20-30$ & & 39.5 \\
\hline Magnesium & $2-10$ & & 7.9 \\
\hline${ }^{90} \mathrm{Sr}$ & & $59-220 \mathrm{dpm} / \mathrm{ml}$ & \\
\hline Sodium & $25-30$ & & 11 \\
\hline${ }^{137} \mathrm{Cs}$ & & $5.25-12.0 \mathrm{dpm} / \mathrm{ml}$ & \\
\hline Uranium & $<0.01$ & & \\
\hline Copper & 0.05 & & 0.03 \\
\hline Aluminum & 0.01 & & 0.06 \\
\hline Silicon & 2.6 & & b.d.1. \\
\hline Iron & 0.1 & & 0.8 \\
\hline Nickel & 0.03 & & b.d.l. b \\
\hline Chromium & 0.05 & & $<0.05$ \\
\hline Dissolved carbon dioxide & 10 & & \\
\hline Bicarbonate $^{\mathbf{a}}$ & $50-80$ & $22-258$ & \\
\hline Carbonate ${ }^{a}$ & $<1$ & $26-136$ & \\
\hline Phosphate & $0.89-3.3$ & $0.11-0.18$ & 1.6 \\
\hline Oxalate & & & $<0.1$ \\
\hline Sulfate & 12 & $28-34$ & 33 \\
\hline Fluoride & 7 & & 1.05 \\
\hline Nitrate & 26 & $19-27$ & 142 \\
\hline Chloride & 5 & $8.1-11.7$ & 13.0 \\
\hline Total solids & 180 & $190-406$ & 461 \\
\hline $\mathrm{pH}$ & $7-8$ & $8.55-10.45$ & \\
\hline Gross $\beta$ & $\times 10^{-4} \mu \mathrm{Ci} / \mathrm{ml}$ & 19-89 cpm/ml (av. & 50) \\
\hline
\end{tabular}


Table 2. Radionuclides in plant streams

\begin{tabular}{|c|c|c|c|c|}
\hline & \multicolumn{4}{|c|}{ Radionuclides (average $\mathrm{dpm} / \mathrm{ml}$ ) } \\
\hline & $90_{\mathrm{Sr}}$ & $137 \mathrm{Ce}$ & ${ }^{60} \mathrm{Co}$ & $\overline{154}$ \\
\hline \multicolumn{5}{|c|}{ Column A, Feb. 10 to Feb. 17} \\
\hline $\mathrm{EB}^{\mathrm{a}}$ & 59 & 6.25 & 1.2 & 0.6 \\
\hline$L-3^{b}$ & 21.6 & 5.80 & 0.97 & -- \\
\hline $\mathrm{L}-4^{\mathrm{C}}$ & 0.04 & 3.09 & 0.89 & 0.41 \\
\hline Minimum & -- & 0.056 & -- & -- \\
\hline Maximum & 0.06 & 6.07 & 1.03 & 0.45 \\
\hline \multicolumn{5}{|c|}{ Column B, Feb. 17 to Feb. 26} \\
\hline $\mathrm{EB}^{\mathrm{a}}$ & 220 & 5.25 & 1.3 & -- \\
\hline$L-3^{b}$ & 7.4 & 5.22 & 0.8 & -- \\
\hline$L-4^{C}$ & 0.02 & 3.11 & 0.79 & 0.32 \\
\hline Minimum & -- & 0.09 & -- & -- \\
\hline Maximum & 0.04 & 8.24 & 0.98 & 0.41 \\
\hline \multicolumn{5}{|c|}{ Column C, Feb. 26 to Mar. 9} \\
\hline $\mathrm{EB}^{\mathrm{a}}$ & 140 & 12.0 & 1.5 & -- \\
\hline$L-3^{b}$ & 30.5 & 11.0 & 1.3 & 0.5 \\
\hline$L-4^{C}$ & 0.015 & 9.87 & 1.13 & 0.34 \\
\hline Minimum & -- & 0.07 & -- & -- \\
\hline Maximum & 0.04 & 14.3 & 1.68 & 0.41 \\
\hline $\mathrm{MPC}_{\mathrm{w}}{ }^{\mathrm{d}}$ & 0.67 & 44 & 111 & 44 \\
\hline
\end{tabular}

aqualization basin - plant feed.

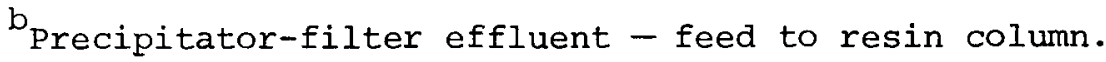

CPlant output.

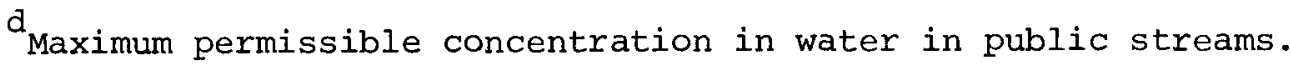



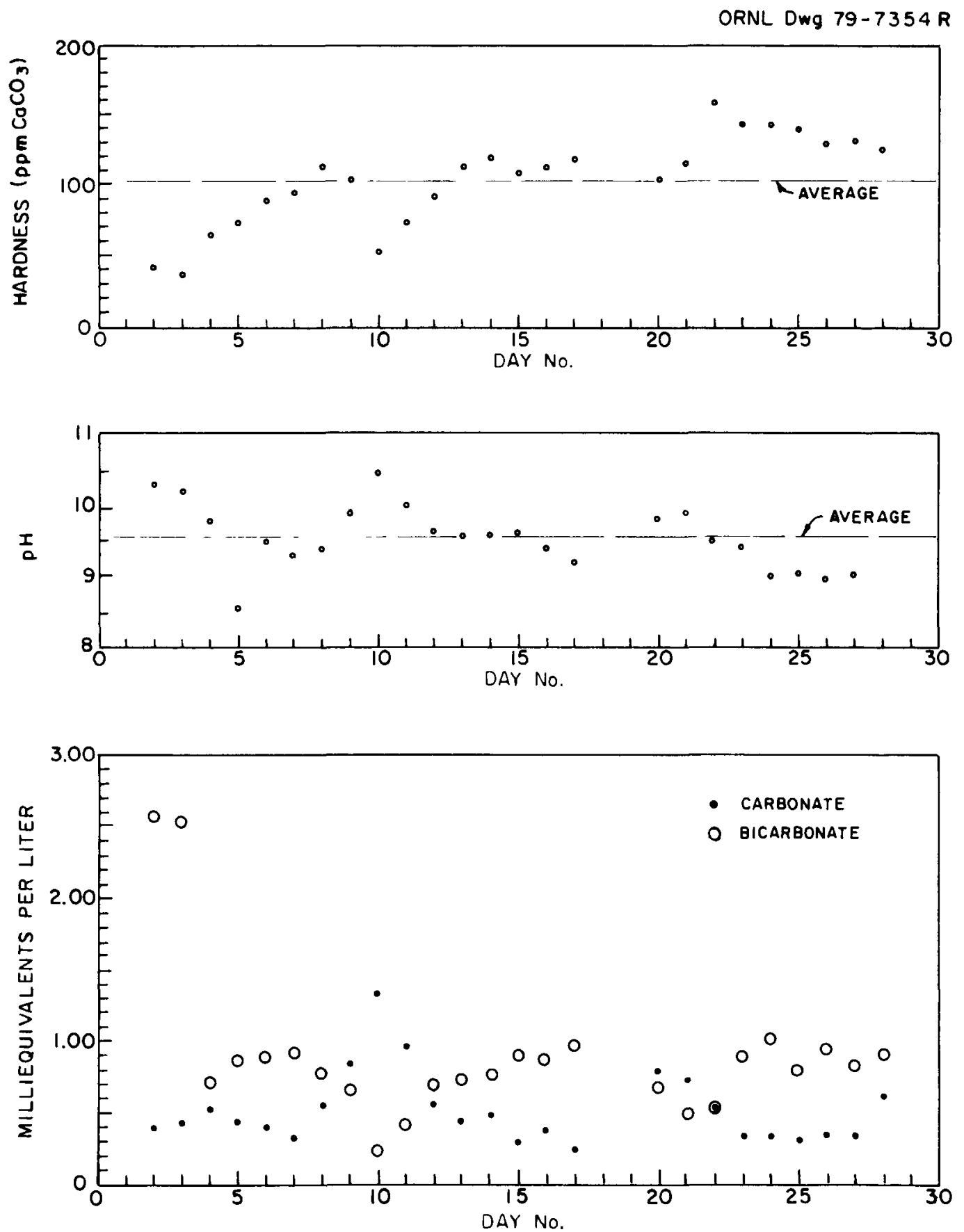

Fig. 1. Composition of plant feed (equalization basin). 
ORNL DWg 79-7355R
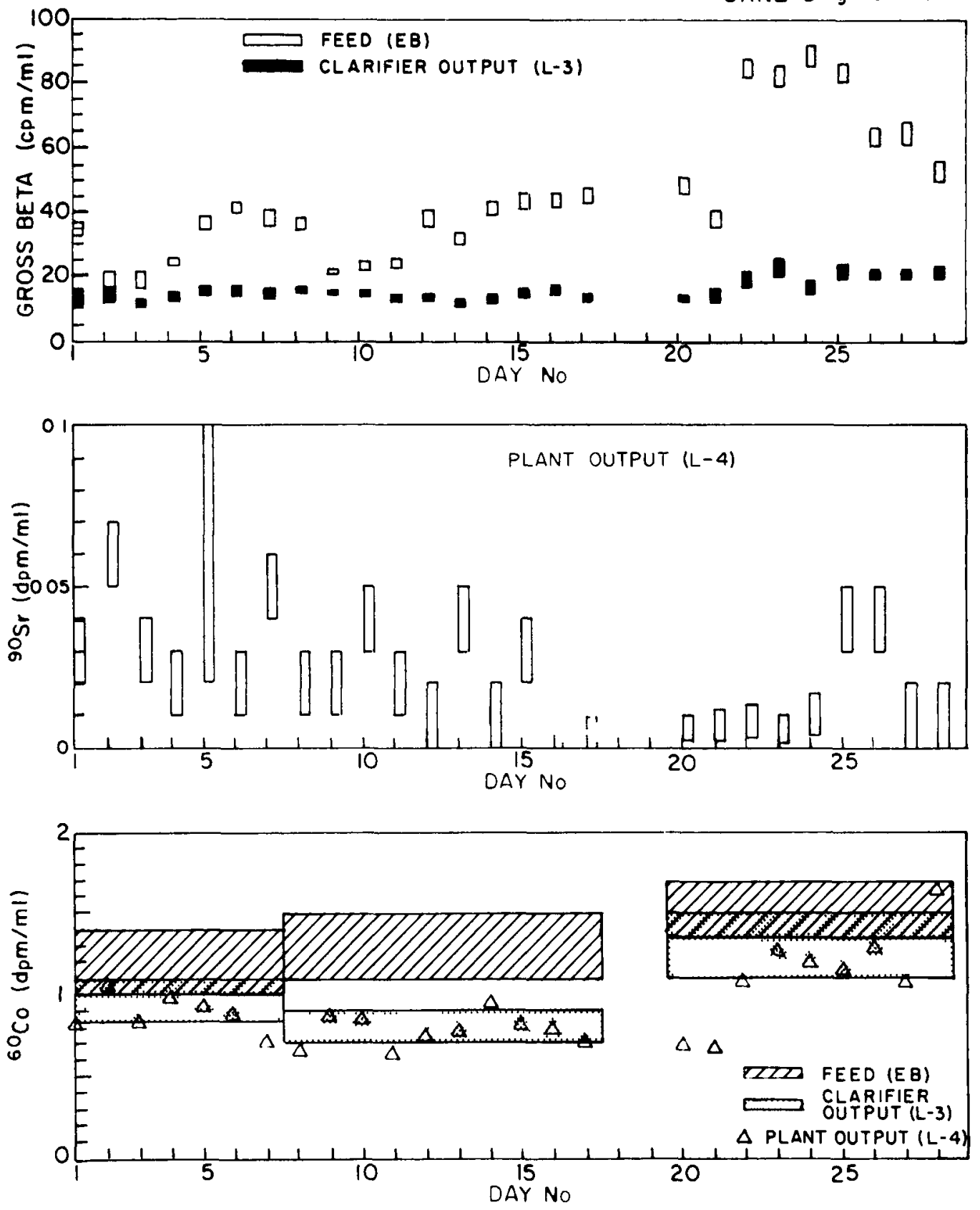

Fig. 2. Radiochemical analyses. 

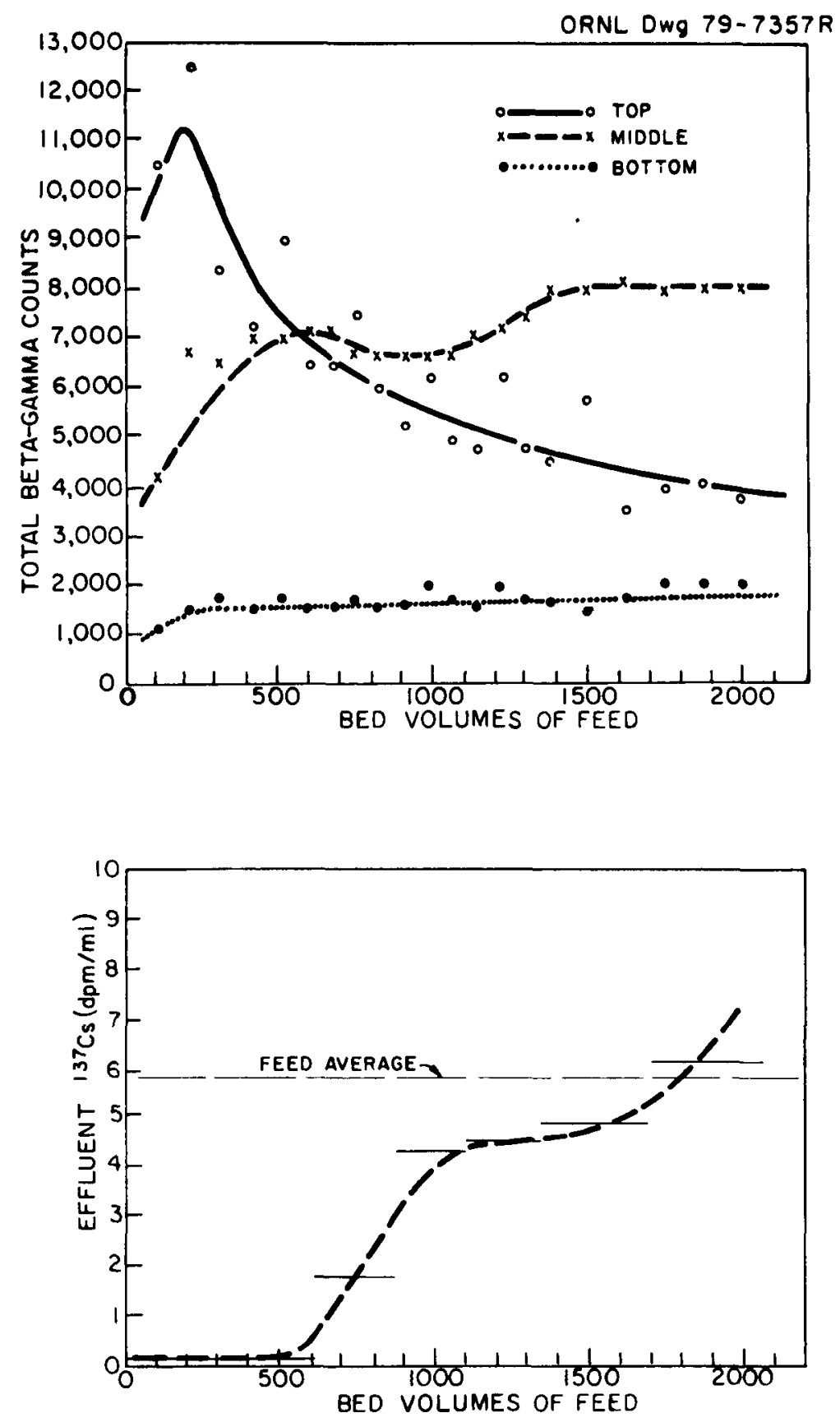

Fig. 3(a). External radiation from resin bed $A$. 

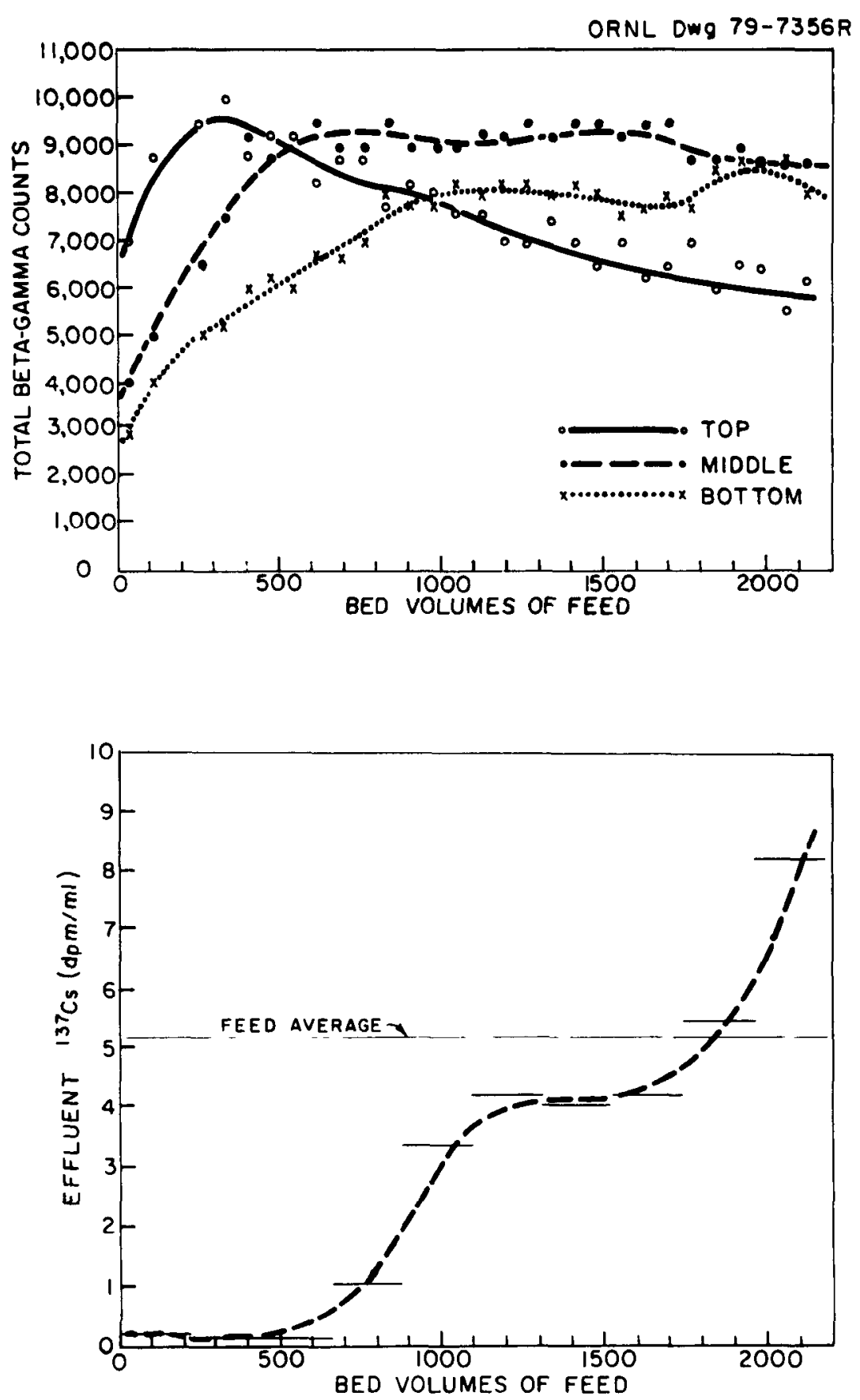

Fig. 3(b). External radiation from resin bed $B$. 

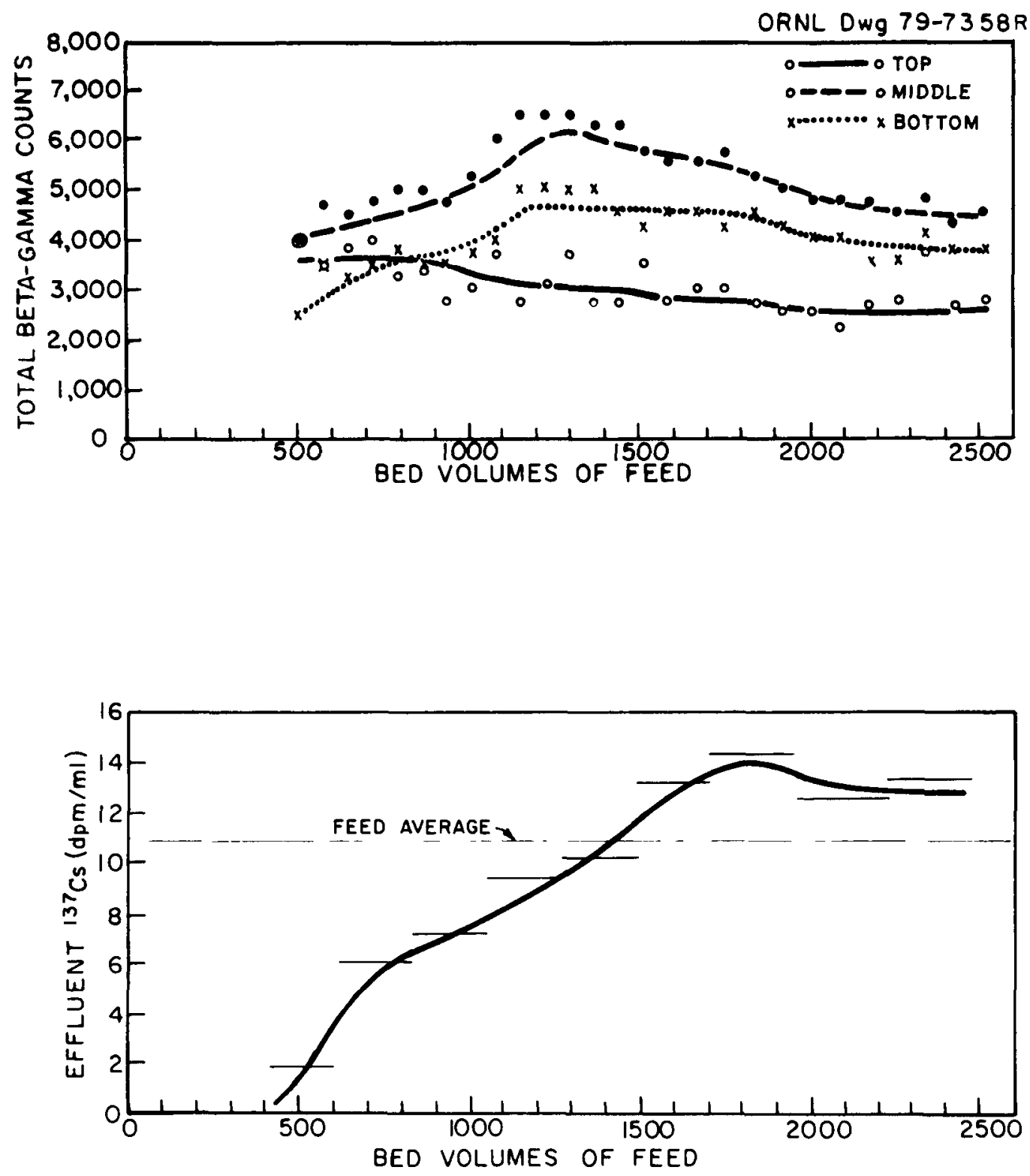

Fig. 3(c). External radiation from resin bed $c$. 
INTERNAL DISTRIBUTION

$\begin{aligned} \text { 1. } & \text { W. D. Burch } \\ \text { 2. } & \text { C. D. Cagle } \\ \text { 3-12. } & \text { J. M. Chilton } \\ \text { 13. } & \text { H. C. Claiborne } \\ \text { 14. } & \text { E. D. Collins } \\ \text { 15. } & \text { J. L. Collins } \\ \text { 16. } & \text { J. H. Coobs } \\ \text { 17. } & \text { G. J. Dixon } \\ \text { 18. } & \text { N. E. Dunwoody } \\ \text { 19. } & \text { R. D. Ehrlich } \\ \text { 20. } & \text { R. W. Glass } \\ 21 . & \text { A. R. Godsey } \\ 22 . & \text { F. E. Harrington } \\ 23 . & \text { L. C. Hensley } \\ 24 . & \text { L. J. King } \\ 25 . & \text { R. E. Lampton }\end{aligned}$

26. L. C. Lasher

27. R. E. Leuze

28. M. H. Lloyd

29. A. L. Lotts

30. E. W. McDaniel

31. J. G. Moore

32. K. J. Notz

33. R. A. Robinson

34. T. G. Scott

35. M. G. Stewart

36-37. Central Research Library

38. ORNL-Y-12 Technical Library Document Reference Section

39-43. Laboratory Records

44. Laboratory Records, ORNL R.C. 45. ORNL Patent Section

\section{EXTERNAL DISTRIBUTION}

46. Office of Assistant Manager, Energy Research and Development, DOE-ORO, P. O. Box E, Oak Ridge, Tennessee 37830

47. Diamond Shamrock Chemical Company, Napco Chemical Division, 1901 Spring Street, Redmond City, California 94063

48. D. E. Large, DOE-ORO, P.O. BOx E, Oak Ridge, Tennessee 37830

49-372. Given distribution as shown in TID-4500 under Nuclear waste Management category (25 copies - NTIS) 